\title{
Kohti minkälaista työelämää?
}

Tuula Heiskanen, Minna Leinonen, Anu Järvensivu \& Simo Aho (toim. 2008). Kohti uutta työelämää? Tutkimuksen näköala työelämän kehitykseen. Tampere University Press.

Tampereen yliopiston työelämän tutkimuskeskuksen 20-vuotisen historian kunniaksi julkaistu teos sisältää 11 työelämän ajankohtaisia aiheita, tulevaisuuden haasteita ja kehitysmahdollisuuksia käsittelevää artikkelia. Teosta voi pitää yhteenvetona keskuksen viimeaikaisesta tutkimus- ja kehittämistoiminnasta. Teoksen ensimmäinen osa "muutoksia ja pysyvyyttä" tarkastelee lähinnä yleisiä työelämän kehitysilmiöitä. Toisessa osassa "tutkimus ja toimiminen" kohteena ovat työpaikkataso ja kehittämishankkeet, joihin keskuksen tutkijat ovat osallistuneet.

Kirjan ensimmäinen osa käsittää kuusi artikkelia. Näistä ensimmäisessä Anu Järvensivu ja Pasi Koski käsittelevät työelämäsuuntautunutta oppimista ja siihen kohdistuvaa tutkimusta osana nykyistä innovaatiodiskurssia. He nostavat esiin oppimisen mikropoliittisen ja ristiriitaisen luonteen. Artikkelin yhtenä pääviestinä on tarve saada oppimiseen preskriptiivisesti ja normatiivisesti suuntautuvaa innovaatiotutkimuksen ja-keskustelun valtavirtaa tunnistamaan tämän nykyistä paremmin ja laventamaan käsitystä työelämässä tapahtuvan oppimisen ehdoista ja mahdollisuuksista.

Seuraavassa artikkelissa Simo Aho ja Robert Arnkil tarjoavat rautaisannoksen suomalaisen työvoimapolitiikan ja-palvelujen viime vuosien uudistuksista eri vaiheineen. Artikkeli valaisee suomalaisen työvoimapolitiikan ristipaineita työmarkkinoita palvelevan päälinjan ja sosiaalipo- liittisemman päälinjan kesken. Kirjoittajat tuovat esiin Suomessa tehtyjen uudistusten varovaisuuden muihin Pohjoismaihin verrattuna niin politiikan sisällöissä kuin palvelujen toteutustavoissa itse taloudessa ja työmarkkinoilla tapahtuneista rajuista käänteistä huolimatta. Antti Saloniemi ja Pekka Virtanen tarkastelevat työn epävarmuuden kokemuksia Tilastokeskuksen vuoden 2003 työolotutkimuksen aineistoilla. Kyseessä on empiirinen ja teoriakriittinen analyysi, joka muotonsa puolesta sopisi sellaisenaan julkaistavaksi myös tieteellisessä lehdessä. Kirjoittajat arvioivat herkullisesti kriittisellä otteella uuden kapitalismin aikalaisanalyyseja (Beck, Castells, Sennett) ja tuovat hyvin esiin joustavaa työtä koskevia suomalaisten työmarkkinoiden erityispiirteitä.

Tuula Heiskanen, Päivi Korvajärvi ja Liisa Rantalaiho kä- 
sittelevät sukupuolen mukaisen työnjaon pysyvyyttä ja siinä viime vuosina tapahtuneita liikahduksia. Artikkeli osoittaa jaon ja sen taustalla olevien sukupuolistuneiden käytännön sitkeyden myös esimerkiksi tietotyössä. Liikahduksia kirjoittajat näkevät kuitenkin ammattien sukupuolikoostumuksessa, työn ja perheen yhteensovittamisessa sekä ammateissa ja niihin sitoutuvassa identiteettiperustassa.

Satu Kalliolan ja Risto $\mathrm{Na}$ karin artikkelin kohde on toimintatutkimus ja sen mahdollisuudet kuntien työelämän muutoksissa. Kuntien viime vuosien muutosten ohella artikkeli esittelee 1990-luvun alkupuolella toteutettua laatu-projektia ja sen jatkoksi syntynyttä laatu-verkostoa ja näiden lähestymistapaa. Kirjoittajat nostavat esiin osallistavan toimintatutkimuksen mahdollisuudet yhteistoiminnallisten toimintatavan muutosten toteuttamisessa kuntien palvelurakennemuutoksen yhteydessä.

Ensimmäisen osan viimeinen artikkeli liikkuu makrotrendien tasolla käsitellen globaalisaation ja ilmastonmuutoksen vaikutuksia työelämään. Siinä Antti Kasvio nostaa työelämän yhteiskuntatieteellisen tutkimuksen tärkeimmäksi tämänhetkiseksi tehtäväksi edesauttaa työn tekemisen tapojen uudistumista ja tähän liittyviä institutionaalisia rakenteita ja poliittisia ratkaisuja vastaamaan paremmin makrotrendeistä aiheutuviin haasteisiin. Hän pitää tässä yhteydessä oikeutettuna puhua jopa edessä olevasta uudesta teollisesta vallankumouksesta.

Kirjan toisen, kehittämispainotteisemman osan avaa Päivi Valkaman ja Anu Järvensivun artikkeli Pirkanmaan seudulla toimivasta Combinno-verkostosta ja tutkijoiden roolista siinä. Artikkelissa analysoidaan yliopistotutkijoiden erilaisia rooleja yritysverkostojen resurssina. Tällaisina rooleina kirjoittajat esittävät tutkijan hankkeen suunnittelijana ja rahoitusten etsijänä, tutkimustiedon välittäjänä, kohtauttajana, työkalujen valmistajana, dokumentoijana, analysoijana ja raportoijana, arvioijana sekä diskurssien luojana, konseptoijana ja teorioiden kehittäjänä.

Jukka Vehviläinen pohtii artikkelissaan arviointitutkimuksen mahdollisuuksia ammatillisen koulutuksen kehittämisessä nuorten osallisuuteen kohdistuneen ESR-hankkeen kokemusten valossa. Artikkelissa käsitellään mielenkiintoisella tavalla arvioinnin ja vallan välisen suhteen ongelmallisuutta. Yhtenä ratkaisuna kirjoittaja nostaa esiin arvioijan tietoisen roolin dialogiin saattajana, uusien näkökulmien avaajana ja tiedontuottajana - ei niinkään tuomarina tai totuuden sanojana.

Karin Filander ja Esa Jokinen problematisoivat oppilaitosten näkökulmasta, näyttäytyykö kehittämistyö nykyajan projektiyhteiskunnassa enemmänkin pakkona kuin mahdollisuutena. Kirjoittajien kriittisen näkemyksen mukaan kehittämistyötä näyttäytyy usein nimenomaan pakkona, jossa kehittämisen autonomia on rajoitettua ja sen tuloksia koskevat odotukset painottavat nopeaa hyödynnettävyyttä ja kapeaa taloudellista välineellisyyttä. Toisaalta kirjoittajien mukaan on löydettävissä myös hyviä esimerkkejä refleksiivisemmästä kehittämistyöstä, jota voitaisiin tukea nykyistä vahvemmin esimerkiksi dialogisen toimintatutkimuksen avulla.
Riikka Kivimäki ja Aija Karttunen käsittelevät terveydenhuollon työntekijöiden työaikoja ja näihin liittyviä erilaisia intressejä. Artikkeli perustuu yhdeksässä yliopistollisessa sairaalassa tai keskussairaalassa tehtyyn kysely- ja toimintatutkimukseen. Tutkimuksen mukaan työaikojen joustoissa korostuvat nykyisin pääosin työpaikan intressit, joskin myös aidosti työntekijälähtöisiä työaikojen suunnittelukäytäntöjä oli löydettävissä. Kirjoittajat kannustavat sairaalaorganisaatioita tasaveroiseen vuoropuheluun joustavista, eri osapuolten intressejä paremmin yhteen sovittavista työajoista.

Liisa Huhdan, Minna Leinosen ja Katja Uosukaisen artikkeli pk-yrityssektorin tasa-arvotyötä koskevista kokemuksista päättää teoksen jälkimmäisen osan. Artikkeli perustuu pirkanmaalaisissa pk-yrityksissä toteutetun kehittämishankkeen tuloksiin. Pk-sektorin tasa-arvotyön erityisiksi haasteiksi kirjoittajat nostavat ajan puutteen, vähäiset henkilöresurssit, konservatiivisuuden ja toiminnan lyhytjänteisyyden. Tasa-arvon edistämistä ei myöskään tyypillisesti mielletä osaksi yritysten kokonaisvaltaista henkilöstön kehittämistyötä. Toisaalta artikkeli nostaa esiin myös positiivisia esimerkkejä kehittämistyöllä aikaan saaduista tuloksista.

Teos käsittelee monenlaisia työelämän muutokseen vaikuttavia trendejä ja tekee yhteenvetoja keskuksen tutkijoiden keskeisistä viimeaikaisista hankkeista. Tässä mielessä se on hyvä läpileikkaus ennen kaikkea keskuksen omaan toimintaan. Työelämän tutkimuksen ja kehittämisen osalta teos painottuu paljolti kuntien ja naisvaltaisten alo- 
jen kysymyksiin. Useassa artikkelissa viitataan myös osallistavaan tai kommunikatiiviseen toimintatutkimukseen, joka onkin ollut ehkä tärkein keskuksen kehittämistyötä ohjannut lähestymistapa. Työelämän tutkijoille teos antaa hyvän mahdollisuuden ajantasaistaa tietonsa Suo- men suurimman yhteiskuntatieteellistä työelämän tutkimusta harjoittavan yksikön toiminnasta. Opiskelukäyttöön kirjaa voi helppolukuisuutensa vuoksi myös suositella mainiosti. Muille lukijoille kirja voi tarjota tärkeitä oivalluksia työelämän muutossuuntien ristiriitaisesta luon- teesta. Kirjan otsikko kysyy:

"Kohti uutta työelämää?". Tähän kysymykseen kirja ei suoranaisesti vastaa, mutta moneen muuhun kylläkin.

TUOMOALASOINI 